\title{
Chronic encephalopathies induced by mercury or lead: aspects of underlying cellular and molecular mechanisms
}

\author{
Lars Rönnbäck, Elisabeth Hansson
}

\begin{abstract}
Long term exposure to low doses of mercury or lead can induce neurasthenic symptoms with slight cognitive deficits, lability, fatigue, decreased stress tolerance, and decreased simultaneous capacity. After exposure to higher concentrations permanent neuropsychological deficits can be seen. The present paper gives a new idea of possible molecular mechanisms underlying the symptoms. Impairments of astrocyte function are probably important, especially due to their capacity to regulate the ionic and amino acid concentration in the extracellular micromilieu, brain energy metabolism, and cell volume. Recent results have shown that these functions are under monoaminergic control. Aspects of therapy are outlined.
\end{abstract}

Long term exposure to mercury may give rise to a syndrome of tremor, variable limb weakness, and ataxia due to damage of cells in the cerebellum. Also, personality changes often characterised by fatigue, stress intolerance, insomnia, irritability, and sometimes impairment of concentration capacity and of short term memory can be seen. The patients often complain of decreased simultaneous capacity and impairments in their ability to talk to several people at the same time. They also complain of increased sensitivity to sound. Similarly, exposure to low doses of lead for long periods can give rise to neurasthenic symptoms. ${ }^{1-5}$ The symptoms are important as they profoundly impair the patient's capacity to work. The nervous system is a primary target for many toxic substances but the anatomical origins of the symptoms are at present not fully understood, although neuronal networks in large parts of the cerebral cortex are believed to be affected.

Little is known about biochemical correlates with

Institute of Neurobiology, Department of Neurology, University of Göteborg, Göteborg, Swreden L Rönnbäck, E Hansson behaviour, probably due to the prominent functional specialisation and cellular heterogeneity even in small brain regions. Neural tissue has a profund specialisation for excitability, which is the basis for brain functions. To establish and maintain this high degree of excitability it is of utmost importance that the extracellular environment is stable. This is especially important as neurones and synapses are densely packed and thus the activity of neurones could affect the activity of other neurones. It thus seems appropriate that half of the brain's volume does not consist of excitable cells but of non-excitable glial cells. These cells have the capacity to isolate neuronal systems and to regulate the neuronal microenvironment. A large mass of evidence now exists showing that astroglia, which constitute the bulk of the glial cells in the cerebral cortex, develop abilities to regulate the extracellular environment of neurones. This ability places these cells in the adaptably important position of changing that environment and therefore modulating the excitability of many neurones simultaneously. Furthermore, these cells have a prominent capacity for oxidative metabolism and they are also considered important for the regulation of brain volume. Recent research has shown that these functions are under adrenergic control and has placed the astroglial cells, as well as neurones, in the position of possible targets for noradrenergic transmission. ${ }^{67}$ It was known many years ago that both mercury and lead accumulate in astrocytes and affect their function. ${ }^{8-13}$

Astrocyte anatomy, properties, and functions Astrocytes constitute more than half of the cell number in the cerebral cortex of higher mammals. ${ }^{14}$ They have long processes that surround blood vessels and synapses, form a continuous subpial and subependymal layer, surround neuronal surfaces, and form a network with other astrocytes by means of gap junctions. These gap junctions are a prominent feature of astrocytes in the brain and many lines of evidence suggest that astrocytes are electrically coupled to each other..$^{15-17}$ In fact, there is evidence for a calcium channel ${ }^{1819}$ that could regulate the permeability of gap junctions. Recently, Cornell-Bell 
and coworkers ${ }^{20}$ showed that glutamate induced increases in cytoplasmic free calcium propagate as waves with the cytoplasm of individual astrocytes and between adjacent astrocytes in confluent cultures. Those propagating waves of calcium suggest that networks of astrocytes may constitute a long range signalling system within the brain. The $\mathrm{Ca}^{2+}$ waves may propagate between the cells by passage of a second messenger through the gap junctions. Potential mediators of the signalling postulated by Cornell-Bell et $a l^{20}$ include the inositol phosphates (for example $\mathrm{IP}_{3}$ ), some other inositol phosphate metabolites, the $\mathrm{Ca}^{2+}$ ion itself, and the flow of electric current. Furthermore, astrocytes possess voltage sensitive ion channels, such as sodium and chloride channels ${ }^{21}$ and several types of potassium channel, including one that is calcium dependent, ${ }^{22}$ and ion channels regulated by glutamate. ${ }^{23}$ Various oscillatory and non-oscillatory $\mathrm{Ca}^{2+}$ responses of astocytes to glutamate have been found. ${ }^{20}{ }^{24}$ Because nerve terminals that release glutamate are close to astrocytic membranes, neuronally released glutamate may trigger $\mathrm{Ca}^{2+}$ responses in astrocytes in situ.

The cells have several important roles in the mammalian brain. For example, it is generally considered that astrocytes are involved in the maintenance of the external $\mathrm{K}^{+}$concentration, ${ }^{25}$ guidance of migrating neurones, ${ }^{26}$ inactivation of neurotransmitters, ${ }^{27} 28$ antigen presentation to macrophages, ${ }^{29}$ and induction of the blood brain barrier..$^{30}$ The astroglial cells produce and secrete trophic factors for the neurones ${ }^{31}$ and if they are severely damaged, neuronal survival might be affected. The cells are differentiated in various brain regions, and there seems to be a great heterogeneity among the astrocytes. ${ }^{32-36}$ Most of our present knowledge about properties of astroglial cells have come from studies of cell culture (fig 1 ).

\section{Membrane receptors on astroglia}

Astrocytes in culture possess receptors for many neurotransmitter substances. Most of those studied so far are linked to cyclic AMP or inositol phosphates as second messengers. ${ }^{32} 3738$ Astroglial $\beta$-adrenoceptors are mainly of the $\beta_{1}$ subtype. ${ }^{39}$ They are coupled to adenylate cyclase, which leads to increases in cyclic AMP. ${ }^{40-42}$ Astrocytes also possess $\alpha_{2}-$ adrenoceptors that mediate an inhibition of cyclic AMP accumulation in the cells. ${ }^{43-45}$ Because $\alpha_{2}$ adrenoceptors inhibit the production of cyclic AMP induced by $\beta$-receptor stimulation, it is likely that both $\alpha_{2}$-and $\beta$-adrenoceptors are expressed on the same cell $^{45}$ and they probably contribute to the control of intracellular cyclic AMP concentrations.

There is strong evidence that the $\alpha_{1}$-receptor subtype is linked to stimulation of inositol phospholipid metabolism on astrocytes grown in primary culture. ${ }^{4647} \alpha_{1}$-Receptor activation thus results in mobilisation and entry of calcium and activation of protein kinase $\mathrm{C}$. The work by Pearce and cowork$\mathrm{ers}^{46}$ showed a stimulation of phosphoinositide hydrolysis achieved by 5-hydroxytryptamine (5HT) and we showed the presence of $5 \mathrm{HT}_{2}$ receptors on astrocytes in primary culture from the cerebral cortex, striatum, hippocampus, and brain stem with a stimulation of turnover of phosphoinositides. ${ }^{48}$

ARE THE RECEPTORS LOCALISED ON THE SAME CELL?

Recent results using single cell microspectrofluorimetry with calcium indicator dyes have shown that the $\alpha, \beta$, and 5HT receptors can be expressed on the same astroglial cell. ${ }^{49}$ Thus it seems that mosaics of receptors are present on the astrocytes. Furthermore, the second messengers of these receptors communicate with each other through intramembrane signals. Peptides, such as vasoactive intestinal peptide (VIP), and noradrenaline were found to act synergistically to increase

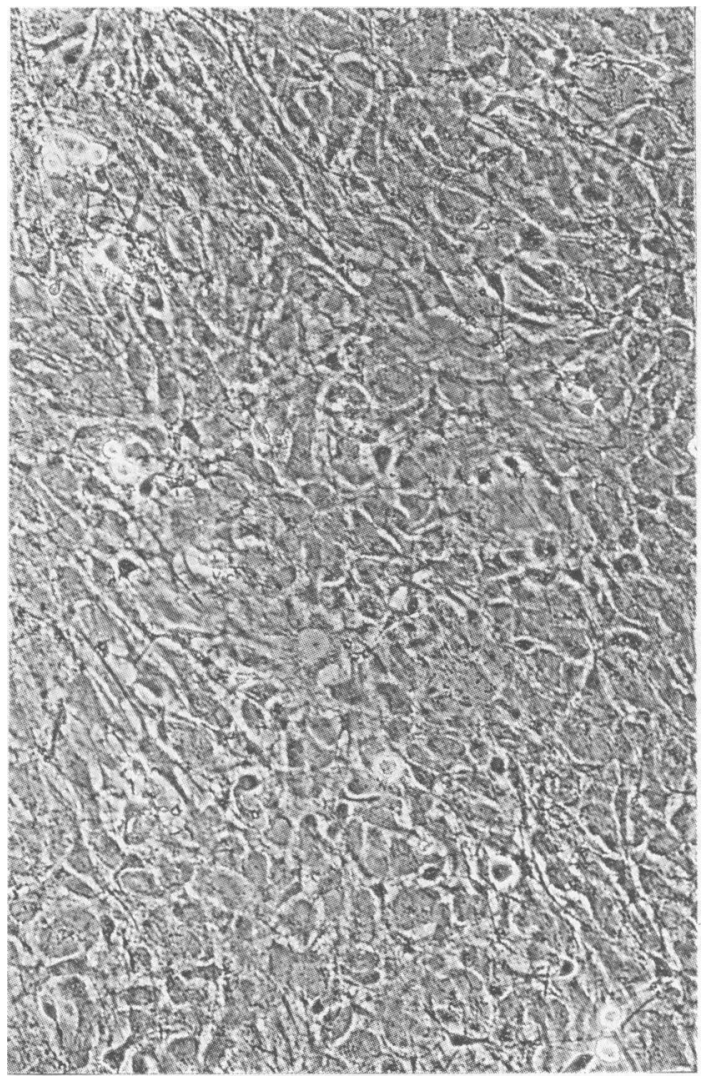

Figure 1 Astroglial cells grown for 14 days in primary culture from newborn rat cerebral cortex. The cells are flat with a central nucleus. They are extensively characterised from a biochemical point of view. For details $\mathrm{see}^{32}$. 


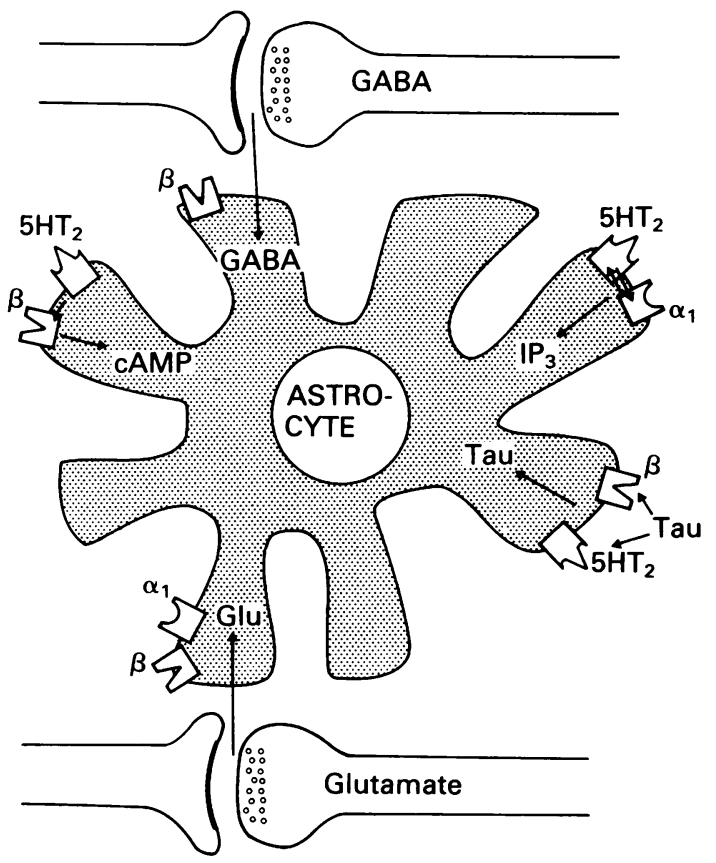

Figure 2 Schematic drawing of an astrocyte with contacts with two synaptic regions, one using glutamate as transmitter and the other using $G A B A$. The astrocyte can register the release of transmitter from the presynaptic terminal, the transmitter activity in the synaptic spatium, and also the electrical activation of the postsynaptic site. As each astrocyte has contact with several synaptic regions via its extensive processes, one cell can register synaptic activities in many neuronal systems. Stimulation of $5 \mathrm{HT}_{2}$ receptors potentiates the $\beta$-receptor induced increase in cyclic $A M P$ and the $\alpha_{1}$-receptor induced increase in inositol phosphates. For details, see ${ }^{47}$. Furthermore, there are interactions between the $\alpha$-and $\beta$-adrenoceptors and the uptake carriers for GABA and glutamate (see also fig 3) and between the $\beta$ and $5 \mathrm{HT}_{2}$ receptors and taurine uptake. For details, see ${ }^{61}$.

cyclic AMP in the cerebral cortex..$^{5051} 5$-Hydroxytryptamine, which has no effect on the formation of cyclic AMP, potentiated the $\beta$-adrenergic stimulation of adenylate cyclase. ${ }^{47}$ The inositol monophosphate $\left(\mathbf{I P}_{1}\right)$ response after simultaneous stimulation with the $\alpha_{1}$ agonist phenylephrine and 5HT was significantly larger than the sum of the individual phenylephrine and 5HT effects. Clonidine, an $\alpha_{2}$ agonist, known to lower cyclic AMP, ${ }^{43}$ potentiated the 5HT stimulated formation of $\mathrm{IP}_{1}$ considerably. Our observation that adrenergic and serotonergic receptors on astrocytes interact are in line with the concept of receptor receptor crosstalk as a means of processing extracellular information (fig 2).

\section{Astroglial receptor function}

Brain glycogen is stored predominently in astrocytes. ${ }^{52}$ It has been shown that both noradren- aline and 5HT can evoke glycogenolysis and that noradrenergic control of glycogen metabolism is exerted through both $\alpha-$ and $\beta$-receptors. ${ }^{5354}$ Furthermore, an increased extracellular $\mathrm{K}^{+}$concentration increased astroglial glycogenolysis. ${ }^{55}$ It has also been found that $\beta$-receptor activation stimulates glucose uptake into astroglial cells $^{56}$ and that noradrenaline stimulates oxidative metabolism in astrocytes but not in neurones in culture. ${ }^{57}$ Interestingly, Magistretti and Schorderet ${ }^{58}$ suggested that the activation of the noradrenergic system together with VIPergic neurones causes potentiated cyclic AMP and glycogenolytic responses to produce metabolic "hot spots" in the cerebral cortex to cope with localised increases in neuronal activity.

Glutamate and $\gamma$-aminobutyric acid (GABA) are two of the most extensively distributed amino acid
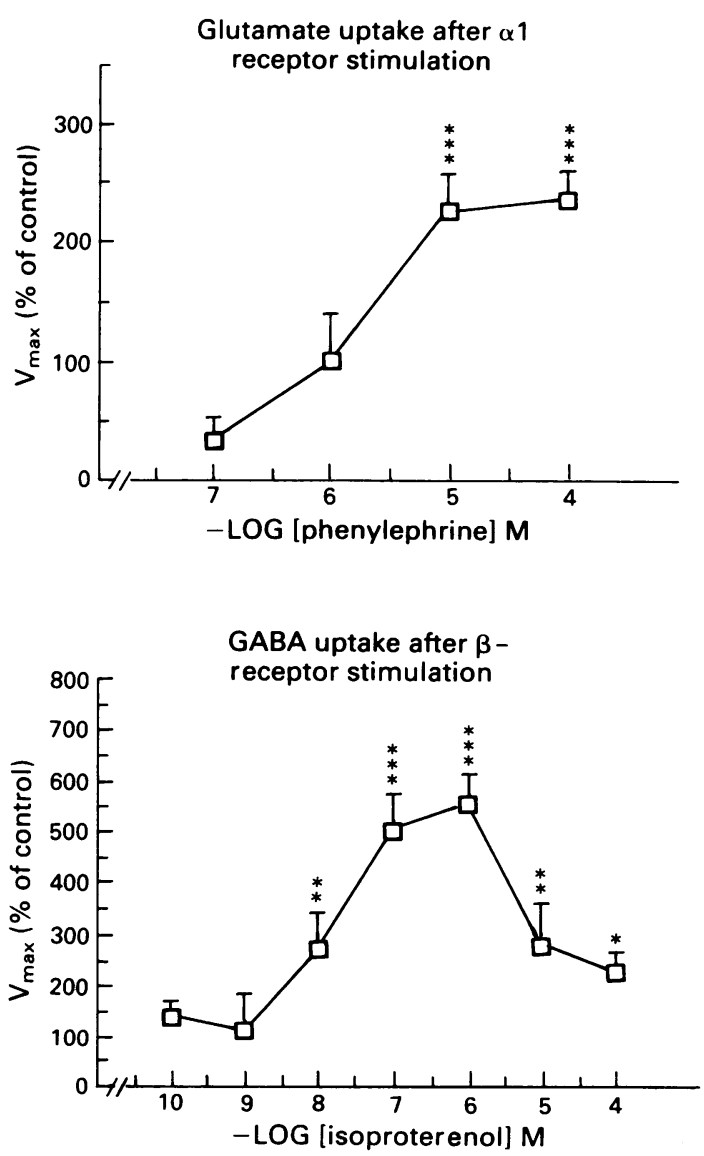

Figure 3 Noradrenaline regulation of glutamate and $\gamma$ aminobutyric acid ( $G A B A$ ) uptake in astroglial enriched primary cultures from newborn rat cerebral cortex. At low $N A$ concentrations the $G A B A$ uptake is increased and the Glu uptake is decreased through $\beta$-receptor activation. At higher NA concentrations, the GABA uptake is unaffected whereas the glutamate uptake is increased through $\alpha_{1}-$ receptor activation. For details, see ${ }^{61}$. 


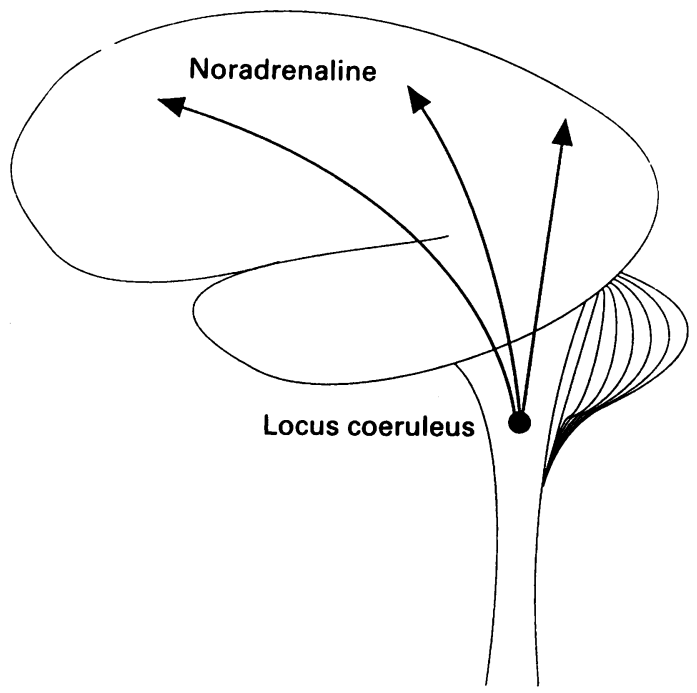

Figure 4 Schematic drawing of the projections from the locus coeruleus, the main origin of noradrenaline, to the cerebral cortex.

transmitters in the cerebral cortex. Excitatory amino acid systems using glutamate as transmitter are widely distributed in the cerebral cortex and in subcortical regions, ${ }^{59}$ especially in the hippocampus, frontal cortex, and in regions associated with sensory function-for example, the superior colliculus and the cochlear nucleus. Glutamate is removed from the extracellular space around synapses by an $\mathrm{Na}^{+}-$ dependent high affinity uptake into both glia and neurones. Astroglial cells possess receptors and uptake carriers for glutamate and $\mathrm{GABA}^{60}$ and the uptake of glutamate by astroglia is considered to be sufficient to account for all glutamate released by neurones. It is generally thought that one role of astrocytes is to accumulate glutamate by active transport. The capacity for GABA uptake is, however, rather low. It has therefore been questioned whether this uptake has any physiological role compared with the reuptake capacity of GABAergic neurones. The glutamate and GABA carriers in astrocytes are controlled by noradrenaline (figs 2 and 3). ${ }^{2861}$ Thus at low $\beta$-adrenergic stimulation, there is an increased GABA uptake and a decreased glutamate uptake into astrocytes whereas at higher concentrations of the $\beta$-agonist both GABA and glutamate uptakes are at the control value. At high noradrenaline concentrations, glutamate uptake is increased, mediated through activation of the $\alpha_{1}$ receptors. It was also shown that the adrenoceptors regulate the intracellular enzymatic activity of glutamic oxaloacetate transaminase, glutamine synthetase, and $\gamma$-aminobutyric acid $\alpha$-ketoglutarate transaminase. $^{28}$
Mercury or lead in chronic low doses: biochemical aspects of neurasthenic symptoms The noradrenergic system is thought to play an important part in attention processes and in responses to stress. Noradrenaline is present in high concentrations in the cerebral cortex. ${ }^{6263}$ The main source is the locus coeruleus in the brain stem (fig 4). The noradrenergic innervation of the cerebral cortex is composed of fine axons, organised predominantly in a plane parallel to the pial surface and spanning a vast expanse of the cortex. ${ }^{6264} 65$

Noradrenaline in low or moderate concentrations (fig 5A) increases astroglial GABA uptake through $\beta$ receptor activation. This leads to a decrease in extracellular GABA which, in turn, results in a decreased inhibition and the possibility of a higher level of transmission in neighbouring synapses and a higher excitation of the postsynaptic membranes. Increased extracellular $\mathrm{K}^{+}$, the normal result of neuronal depolarisation, triggers both pump activity and also astrocytic metabolism of glucose and glycogen. ${ }^{5566}$ Metabolites are formed such as pyruvate and $\alpha$-ketoglutarate, which are released to the neurones. Also, lactate is formed and this leads to a decrease in $\mathrm{pH}$. Together with the active uptake of $\mathrm{K}^{+}$and $\mathrm{Cl}^{-}$by $\mathrm{Na}^{+}$dependent processes, cell volume is increased. ${ }^{67-70}$ In addition, an increased glucose uptake and an increased glycogen and glucose breakdown are directly induced by $\beta$-receptor activation. ${ }^{5671}$ It should be noted that astroglial GABA uptake is of high affinity and low velocity ${ }^{72}$ and therefore regulation of GABA uptake by astrocytes probably has a minor role in synaptic activity that is more modulatory in nature. $\beta$-Receptor stimulation also leads to a diminished glutamate uptake, which might allow transmitter release to generate a higher glutamate concentration at the postsynaptic site. Furthermore, a reduction of the uptake could increase the resting extracellular glutamate concentration with the result that synaptically released glutamate produces a larger postsynaptic response. Accumulated extracellular glutamate has been shown to induce glyconeogenesis with an increase in glycogen and a decrease in glucose utilisation. Although it has been shown that gluconeogenesis does not play any prominent part in the central nervous system, it might to some extent build up local energy or energy rich substances in neighbouring neuronal systems. If required, it might on the other hand, serve as a self regulating system to decrease the metabolism and thereby inhibit neuronal activity. After some period, regulatory mechanisms probably lead to an increased GABA release and, if the uptake is still high, some modulation of the synaptic activity could be expected. On the other hand, if the noradrenaline concentration is further increased, the GABA uptake through $\beta$ receptor activation (at higher concentrations) will 
A. Low $\alpha_{1}$ and $\beta$-receptor activation of the astrocyte

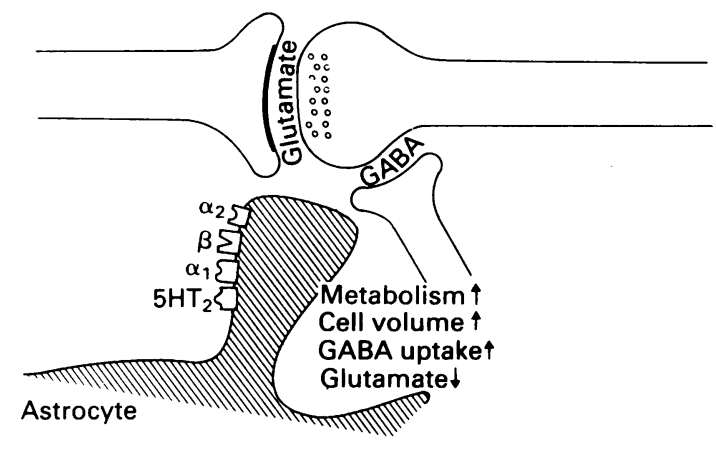

B. High $\alpha_{1}$ and $\beta$-receptor activation of the astrocyte

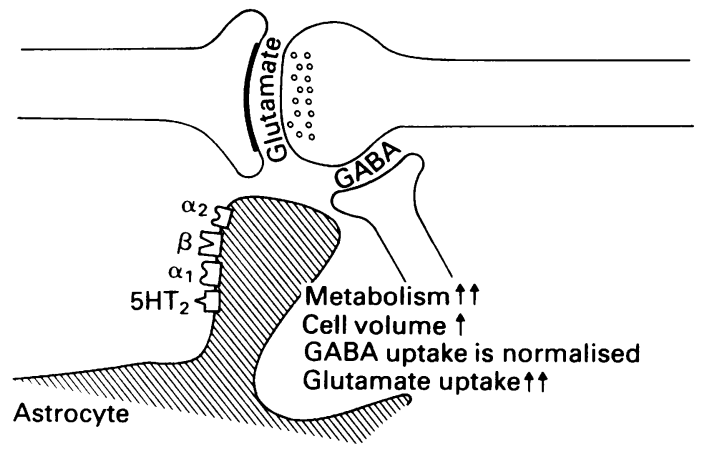

Figure 5 Schematic drawing of a glutamatergic synapse with pre and postsynaptic membranes and an astroglial process. Even an inhibitory synapse is shown with $G A B A$ as the transmitter. The glial process expresses adrenergic as well as $5 \mathrm{HT}_{2}$ receptors.

(A) At low noradrenaline concentration the astroglial $G A B A$ uptake is increased and the glutamate uptake is decreased via activation of astroglial $\beta$-adrenoceptors. The result will be an increased synaptic activity in the excitatory synapse. Furthermore, $\beta$-receptor activation leads to

increased glucose uptake and increased oxidative metabolism. There is also an increase in cell volume.

(B) At high noradrenaline concentration the astroglial $G A B A$ uptake is at the control level whereas the glutamate uptake is increased. The neuronal excitability increases (see text). Stimulation of the $\alpha_{1}$-receptor potentiates the $\beta$ receptor activated energy metabolism and the cell volume increases further.

decrease to control (ordinary) levels, leading to the previous degree of inhibition.

At higher noradrenaline concentrations (fig 5B), $\alpha_{1}$-receptor activation results in an increased uptake of glutamate. This might be important in the state of high extracellular glutamate, which in itself mediates: (1) a high $\mathrm{Ca}^{2+}$ uptake into both neurones and glial cells with resultant low extracellular $\mathrm{Ca}^{2+}$ concentrations and thereby increased neuronal excitability ${ }^{74}$; (2) a glial depolarisation with increased extracellular $\mathrm{K}^{+}$that results in a decreased glial uptake of glutamate; and (3) an increase in volume with a decreased extracellular space and a further increase in the extracellular concentration of glutamate. Furthermore, $\alpha_{1}$-receptor stimulation has been shown to potentiate the $\beta$-receptor activated glycogenolysis. ${ }^{53}$ Thus both neuronal excitability and astroglial metabolism increase, and so also does the cell volume. Hence, activation of astroglial adrenergic receptors might stimulate neurotransmission by regulation of the extracellular milieu and also the astroglial energy metabolism. The resultant decrease in $\mathrm{pH}$ and increase in cell volume with decreased extracellular space and increased tortuosity ${ }^{73}$ might be factors of importance in the self regulation of the stimulation.

What happens after exposure to low doses of mercury or lead? It has been shown that both mercury and lead inhibit the astroglial capacity to take up glutamate ${ }^{7576}$ (fig 6) and even low concentrations will inhibit the activity of glutamine synthetase ${ }^{76-78}$ the enzyme that converts glutamate to glutamine in astroglia. ${ }^{60}$ If there is a slowly progressing disturbance of astroglial glutamate uptake, or glutamine synthetase activity, or both, then synaptic glutamate transmission will decrease to compensate and less glutamate will probably be released. A decreased neuronal activity mostly results in an upregulation of surface receptors ${ }^{790}$ and it might be that the glutamate receptors will become more sensitive. Under all circumstances cortical glutamate transmission probably decreases with a secondary decrease in transmission in other cortical neurotransmitter systems. As a regulatory consequence, the activity of the locus coeruleus will decrease to some extent and as far as can be expected from the role of cortical noradrenaline activity this might correspond to the symptoms that these patients report, namely, fatigue and lowered alertness.

The problems that appear if there is a prominent noradrenergic activation in this situation with a decreased astroglial uptake of extracellular glutamate can be pronounced. The glutamate concentration rises rapidly either in the whole cortex or locally. Cell volume probably increases and it seems that the biochemical changes correspond to the clinical situation of insufficiency, lability, and headache.

If on the other hand there is a less prominent noradrenergic activation then it is more probable that the glutamate transmission does not work effectively or distinctly due to delays in uptake from the synaptic space. This might lead to difficulties in activating many synapses in parallel. As cell volume probably increases somewhat the extracellular space decreases, which further augments the difficulties. These might be the biochemical correlates with the clinical situ- 

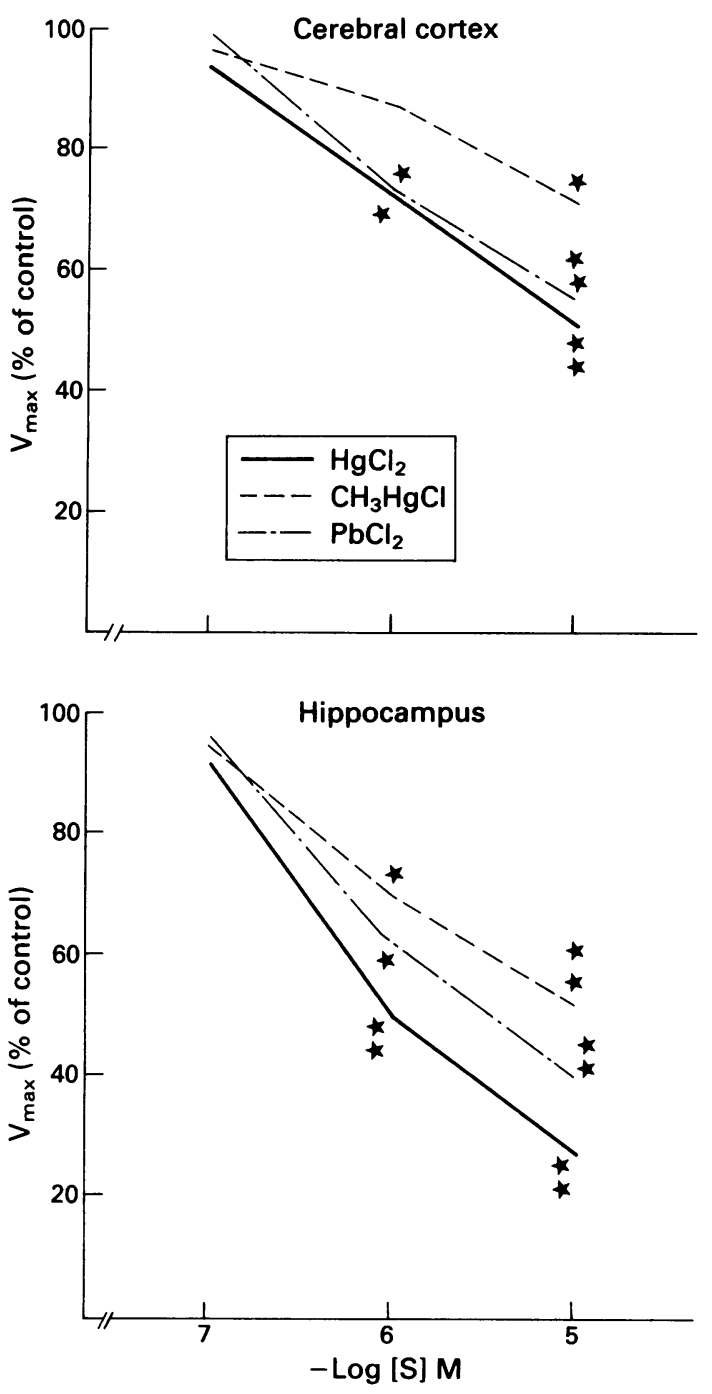

Figure 6 High affinity uptake of ${ }^{3} \mathrm{H}$ glutamate in astroglial primary cultures from rat cerebral cortex and hippocampus after incubation for 60 minutes in $\mathrm{HgCl}_{2}$ or $\mathrm{PbCl}_{2}$ or for 30 minutes in $\mathrm{CH}_{3} \mathrm{HgCl}$ in the concentrations $10^{-7}-10^{-5} \mathrm{M}$. There is a decrease in glutamate uptake, more prominent in the hippocampus, even at the low mercury or lead concentrations. Similar results were obtained from cultures incubated for six days at $10^{-6} \mathrm{M}$ of the respective metal salt with changes of the medium every day.

${ }^{\star} p<0.05 ;{ }^{\star \star} p<0.01$ compared to control; Student's $t$ test. For details, see ${ }^{76}$.

ation of diminished simultaneous capacity, often reported by the patients.

Noradrenaline in very low concentrations may, on the other hand, lead to a diminished inhibition by an increased astroglial uptake of GABA mediated by stimulation of $\beta$-receptors. This will "push the system" and prevent the glutamate receptors from being down regulated too much. Furthermore, a slight $\beta$-receptor activation increases metabolism. In this context, it is interesting to take into account that stimulation of $5 \mathrm{HT}_{2}$ receptors on astroglial cells potentiate the $\beta$-receptor activated cyclic AMP. ${ }^{47}$ Furthermore, it was shown that $5 \mathrm{HT}_{2}$ receptor activation to some extent stimulated the $\alpha_{1}$-receptor induced formation of inositol phosphate. Hypothetically, it might thus be valuable in the clinical situation to have a slight noradrenaline and a slight 5HT activation even though more specific receptor stimulation is required.

Exposure to even higher mercury or lead concentrations might severely affect astroglial uptake and give rise to a prominent increase in extracellular glutamate concentration. As high extracellular glutamate is cytotoxic ${ }^{81}$ sensitive neurones might be damaged, especially neurones in the CA1 region in the hippocampus, ${ }^{82}$ resulting in memory disturbances and other permanent cognitive deficits.

\section{Conclusions}

Recent research on astroglia characteristics carried out mostly on cell culture models has shown that these cells, intimately associated and intermingled with other neuroglia and with neurones, serve important functions in regulating the extracellular microenvironment, including neuronal excitability and metabolism. The cells serve supportive and protective functions towards the neurones and they have a great capacity for regulation of volume. From this view, a behavioural model is presented that enlightens cellular and molecular mechanisms hypothetically underlying symptoms of non-focal encephalopathy such as increased fatigue, stress intolerance, and a slightly decreased cognitive capacity. The hypothesis presented is based on many lines of evidence suggesting that astroglia are targets for noradrenergic and serotoninergic activation and thereby regulate the neuronal extracellular milieu including amino acids-for example, glutamateand ions-for example, $\mathrm{Ca}^{2+}, \mathrm{K}^{+}$, and $\mathrm{Cl}^{-}$, and $\mathrm{Na}^{+}$. Impairment of these astroglial functions, especially the high affinity glutamate uptake, by mercury or lead might lead to a less distinct glutamate transmission and a glutamate "overflow" that could result in the clinical symptoms. At higher metal concentrations the astroglial glutamate uptake is impaired even more and the extracellular glutamate might reach concentrations that are cytotoxic to neurones. Some brain regions, especially the CA1 pyramidal cells in the hippocampus are especially vulnerable, probably due to their high density of N-methyl-D-aspartate receptors. Slight noradrenaline and $5 \mathrm{HT}$ activation may help the clinical situation.

This work was supported by grants from the Swedish 
Work Environmental Health Fund (grant No 900217), the Central Experimental Animal Committee (grant No 91-32), and Torsten and Ragnar Söderberg's Foundations. We thank Torben Kling-Pedersen for producing figs 2,4 , and 5 . The skilful technical assistance of Maria Wågberg and Siw Tuneberg is highly appreciated.

Requests for reprints to: Dr Lars Rönnbäck, Institute of Neurobiology and Department of Neurology, University of Göteborg, PO Box 33 031, S-400 33 Göteborg, Sweden.

1 Petit TL. Developmental effects of lead: its mechanism in intellectual functioning and neuronal plasticity. Neurotoxicology 1986;7:483-96.

2 Dietrich KN, Krafft KM, Bornschein RL, Hammond RB, Berger O, Succop PA, et al. Low-level fetal lead exposure effect on neurobehavioral development in early infancy. Pediatrics 1987;80:721-730.

3 Bellinger D, Leviton A, Waternaux C, Needleman H, Rabinowitz $M$. Low-level lead exposure, social class, and infant development. Neurotoxicol Teratol 1989;10:497-503.

4 Bergoni M, Borella P, Fantuzzi G, Vivoli G, Sturloni N, Cavazzuti G, et al. Relationship between lead exposure indicators and neuropsychological performance in children. Dev Med Child Neurol 1989;31:181-90.

5 Needleman HL, Schell A, Bellinger D, Leviton A, Allred EN. The long-term effects of exposure to low doses of lead in childhood. New England J Med 1990;322:83-8.

6 Stone EA, Ariano MA. Are glial cells targets of the central noradrenergic system? A review of the evidence. Brain Res Rev 1989;14:297-309.

7 Hansson E, Rönnbäck L. Adrenergic receptor regulation of amino acid neurotransmitter uptake in astrocytes. Brain Res Bull 1992 (in press).

8 Oyake Y, Tanaka M, Kubo H, Cichibu H. Neuropathological studies on organic mercury poisoning with special reference to the staining and distribution of mercury granules. Advances in Neurological Sciences 1966;10:744-50.

9 Takeuchi T. Biological reactions and pathological changes in human beings and animals caused by organic mercury contamination. In: Hartung R, Dinman BD, (eds). Environmental Mercury Contamination. Ann Arbor: Ann Arbor Science, 1972:247-89.

10 Choi BH, Lapham LW, Amin-Zaki L, Saleem T. Abnormal neuronal migration, deranged cerebral cortical organization, and diffuse white matter astrocytosis of human fetal brain: a major effect of methylmercury poisoning in utro. J Neuropath Exp Neurol 1978;37:719-33.

11 Holtzman D, DeVries C, Nguyen $\mathrm{H}$, Olson J, Bensch $\mathrm{K}$. Maturation of resistance to lead encephalopathy: cellular and subcellular mechanisms. Neurotoxicology 1984;5:97-124.

12 Tiffany-Castiglioni E, Zmudzki J, Bratton GR. Cellular targets of lead neurotoxicity: in vitro models. Toxicology 1986; 42:303-15.

13 Tiffany-Castiglioni E, Sierra EM, Wu J-N, Rowles TK. Lead toxicity in neuroglia. Neurotoxicology 1989;10:417-44.

14 Kimelberg HK. Primary astrocyte cultures-a key to astrocyte function. Cell Mol Neurobiol 1983;3:1-16.

15 Kettenmann H, Orkand RK, Schachner M. Coupling among identified cells in mammalian nervous system cultures. $J$ Neurosci 1983;3:506-16.

16 Kettenmann H, Ransom BR. Electrical coupling between astrocytes and between oligodendrocytes studied in mammalian cell cultures. GLIA 1988;1:64-73.

17 Ransom BR, Kettenmann H. Electrical coupling, without dye coupling, between mammalian astrocytes and oligodendrocytes in cell culture. GLIA 1990;3:258-66.

$18 \mathrm{MacVicar}$ BA. Voltage-dependent calcium channels in glial cells. Science 1984;226:1345-7.

19 Barres BB, Chun LLY, Corey DP. Calcium current in cortical astrocytes: induction by cAMP and neurotransmitters and permissive effect of serum factors. $J$ Neurosci 1989;9:3169-75.
20 Cornell-Bell AH, Finkbeiner SM, Cooper MS, Smith SJ. Glutamate induces calcium waves in cultured astrocytes: longrange glial signaling. Science 1990;247:470-3.

21 Bevan S, Chiu SY, Gray PTA, Ritchie JM, The presence of voltage-gated sodium, potassium and chloride channels in rat cultured astrocytes. Proc $R$ Soc Lond (Biol) 1985;225: 299-313.

22 Quandt FN, MacVicar BA. Calcium activated potassium channels in cultured astrocytes. Neuroscience 1986;19:29-41.

23 Usowicz MM, Gallo V, Cull-Candy SG. Multiple conductance channels in type-2 cerebellar astrocytes activated by excitatory amino acids. Nature 1989;339:380-3.

24 Nilsson M, Hansson E, Rönnbäck L. Agonist evoked $\mathrm{Ca}^{2+}$ transients in primary astroglial cultures-modulatory effects of valproic acid GLIA 1992 (in press).

25 Walz W, Hertz L. Functional interactions between neurons and astrocytes. II. Potassium homeostasis at the cellular level. Prog Neurobiol 1983;20:133-83.

26 Rakic P. Neuron-glial interaction during brain development. Trends Neurosci 1971;4:184-7.

27 Schousboe A. Metabolism and function of neurotransmitters. In: Pfeiffer S, ed. Neuroscience Approached Through Cell Culture, Vol 1. Boca Raton, Florida: CRC Press, 1982:107-41.

28 Hansson E, Rönnbäck L. Regulation of glutamate and GABA transport by adrenoceptors in primary astroglial cell cultures. Life Sci 1989;44:27-34.

29 Sun D, Wekerle H. Ia-restricted encephalitogenic T lymphocytes mediating EAE lyse autoantigen-presenting astrocytes. Nature 1986;320:70-2.

30 Janzer RC, Raff MC. Astrocytes induce blood-brain barrier properties in endothelial cells. Nature 1987;325:253-7.

31 Schwartz JP. Stimulation of nerve growth factor mRNA content in $\mathrm{C} 6$ glioma cells by a $\beta$-adrenergic receptor and by cyclic AMP. GLIA 1988;1:282-5.

32 Hansson E. Astroglia from defined brain regions as studied with primary cultures. Prog Neurobiol 1988;30:369-97.

33 Hansson E. Regional heterogeneity among astrocytes in the central nervous system. Neurochemistry International 1990, 16:237-45.

34 Lerea LS, McCarthy KD. Astroglial cells in vitro are heterogeneous with respect to expression of the $\alpha_{1}$-adrenergic receptor. GLIA 1989;2:135-47.

35 Wilkin GP, Marriott DR, Cholewinski AJ. Astrocyte heterogeneity. Trends Neurosci 1990;13:43-6.

36 Nilsson $\dot{M}$, Hansson E, Rönnbäck L. Heterogeneity among astroglial cells with respect to 5HT-evoked cytosolic $\mathrm{Ca}^{2+}$ responses. A microspectrofluorimetric study on single cells in primary culture. Life Sci 1991;49:1339-50.

37 Murphy S, Pearce B. Functional receptors for neurotransmitters on astroglial cells. Neuroscience 1987;22:381-94.

38 Kimelberg HK, ed. Glial cell receptors. New York: Raven Press, 1988

39 McCarthy KD. An autoradiographic analyses of beta adrenergic receptors on immunocytochemically defined astroglia. J Pharmacol Exp Ther 1983;226:282-90.

40 Van Calker D, Hamprecht B. Effects of neurohormones on glial cells. In: Federoff S, Hertz L, eds. Advances in cellular neurobiology, Vol I. New York: Academic Press, 1980:31-67.

41 Hansson E. Primary cultures from defined brain areas; effects of seeding time on the development of $\beta$-adrenergic- and dopamine-stimulated cAMP-activity during cultivation. Developmental Brain Research 1985;21:187-92.

42 Salm AK, McCarthy KD. Expression of beta-adrenergic receptors by astrocytes isolated from adult rat cortex. GLIA 1989;2:346-52.

43 Hauser KL. Adrenergic receptors in glioblast cultures from newborn rat cortex. Experientia 1977;33:805.

44 McCarthy KD, DeVellis J. Alpha-adrenergic receptor modulation of beta-adrenergic adenosine and prostaglandin $E$ increased adenosine $3^{\prime}, 5^{\prime}$ cyclic monophosphate levels in primary cultures of glia. Journal of Cyclic Nucleotide Research 1978;4:15.

45 Van Calker D, Muller M, Hamprecht B. Adrenergic $\alpha$ - and $\beta$ receptors expressed by the same cell type in primary cultures of perinatal mouse brain. $J$ Neurochem 1978;30:713-8.

46 Pearce B, Cambray-Deakin M, Morrow C, Grimble J, Murphy $S$. Activation of muscarinic and of $\alpha_{1}$-adrenergic receptors on astrocytes results in the accumulation of inositol phosphates. $J$ Neurochem 1985;45:1534-40.

47 Hansson E, Simonsson P, Alling C. Interactions between cyclic AMP and inositol phosphate transduction systems in astrocytes in primary culture. Neuropharmacology 1990; 29:591-8. 
48 Hansson E, Simonsson P, Alling C. 5-Hydroxytryptamine stimulates the formation of inositol phosphate in astrocytes from different regions of the brain. Neuropharmacology 1987; 26:1377-82.

49 Nilsson $M$, Hansson E, Rönnbäck $L$. Adrenergic and $5 H^{2}$ receptors on the same astroglial cell. A microspectrofluorimetric study on cytosolic $\mathrm{Ca}^{2+}$ responses on single cells in primary culture. Developmental Brain Research 1992 (in press).

50 Chneiweiss H, Glowinski J, Prémont J. Vasoactive intestinal polypeptide receptors linked to an adenylate cyclase, and their relationship with biogenic amine- and somatostatin-sensitive adenylate cyclases on central neuronal and glial cells in primary cultures. $J$ Neurochem $1985 ; 44: 779-86$.

51 Hansson E, Rönnbäck L. Interaction between catecholamines and vasoactive intestinal peptide in cultured astrocytes. Neuropharmacol 1988;27:295-300.

52 Ibrahim MZM. Glycogen and its related enzymes of metabolism in the central nervous system. Adv Anat Embryol Cell Biol 1975;52:5-89.

53 Cambray-Deakin M, Pearce B, Morrow C, Murphy S. Effects of neurotransmitters on astrocyte glycogen stores in vitro. $J$ Neurochem 1988;51:1852-7.

54 Subbarao KV, Hertz L. Effect of adrenergic agonists on glycogenolysis in primary cultures of astrocytes. Brain Res 1990;536:220-6.

55 Cambray-Deakin M, Pearce B, Morrow C, Murphy S. Effects of extracellular potassium on glycogen stores of astrocytes in vitro. J Neurochem 1988;51:1846-51.

$56 \mathrm{Hsu}$ CC, Hsu CS. Effect of isoproterenol on the uptake of ${ }_{14}(C)$ glucose into glial cells. Neurosci Res 1990;9:54-8.

57 Subbarao KV, Hertz L. Noradrenaline induced stimulation of oxidative metabolism in astrocytes but not in neurons in primary cultures. Brain Res 1990;527:346-9.

58 Magistretti PJ, Schorderet M. VIP and noradrenaline act synergistically to increase cyclic AMP in cerebral cortex. Nature 1984;308:280-2.

59 Cotman CW, Monaghan DT, Ottersen OP, Storm-Mathisen J. Anatomical organization of excitatory amino acid receptors and their pathways. Trends Neurosci 1987;10:273-80.

60 Hertz L, Schousboe A. Interactions between neurons and astrocytes in the turnover of GABA and glutamate. GABA Neurotransmission. Brain Res Bull 1980;52:389-95.

61 Hansson E, Rönnbäck L. Receptor regulation of glutamate, GABA and taurine high affinity uptake into astrocytes in primary culture. Brain Res 1991;548:215-21.

62 Moore RY, Bloom FEA. Central catecholamine neuron systems: anatomy and physiology of norepinephrine and epinephrine systems. Annual Review of Neuroscience 1979;2:113-68.

63 Parnavelas JG, Papadopoulos GC. The monoaminergic innervation of the cerebral cortex is not diffuse and nonspecific. Trends Neurosci 1989;12:315-9.

64 Morrison JH, Molliver ME, Grzanna R, Coyle JT. The intracortical trajectory of the coeruleo-cortical projection in the rat: a tangentially organized cortical afferent. Neuroscience $1981 ; 6: 139-58$.

65 Foote SL, Bloom FE, Aston-Jones G. Nucleus locus coeruleus: new evidence of anatomical and physiological specificity.
Physiol Rev 1983;63:844-914.

66 Cummins CJ, Glover RA, Sellinger OZ. Neuronal cues regulate uptake in cultured astrocytes. Brain Res 1979;170:190-3.

67 Walz W, Hinks EC. Carrier mediated $\mathrm{KCl}$ accumulation accompanied by water movements is involved in the control of physiological $\mathrm{K}^{+}$levels by astrocytes. Brain Res 1985;343: 44-51.

68 Walz W. Potassium channels and carriers in glial cell membranes. Advances in Bioscience 1986;61:145-54.

69 Kimelberg HK, Ransom BR. Physiological and pathological aspects of astrocytic swelling. In: Fedoroff $S$, Vernadakis $A$, eds. Astrocytes, Vol 3, Cell Biology and Pathology of Astrocytes. Academic Press, Orlando: 1986:129-66.

70 Staub F, Baethmann A, Peters J, Weight H, Kemaski O. Effects of lactacidosis on glial cell volume and viability. J Cereb Blood Flow Metab 1990;10:866-76.

71 Rosenberg PA, Dichter MA. A small subset of cortical astrocytes in culture accumulates glycogen. Int J Dev Neurosci 1987; 5:227-35.

72 Hansson E, Eriksson P, Nilsson M. Amino acid and monoamine transport in primary astroglial cultures from defined brain regions. Neurochem Res 1985;10:1335-41.

73 Somjen GG. Interstitial ion concentration and the role of neuroglia in seizures. In: Wheal HV, Schwartzkran PA, eds. Electrophysiology of Epilepsy. New York: Academic Press, 1984:303-41.

74 Ward AA. Physiological basis of chronic epilepsy and mechanisms of spread. In: Delgado Escueta AV, Wasterlain CG, Treiman DM, Porter RJ, eds. Advances in Neurology, Vol 34, Status Epilepticus. New York: Raven Press, 1983:189-97.

75 Brookes N. Specificity and reversibility of the inhibition by $\mathrm{HgCl}_{2}$ of glutamate transport in astrocyte cultures. $J$ Neurochem 1988;50:1117-22.

76 Rönnbäck L, Hansson E. ${ }^{3} \mathrm{H}$-glutamate uptake and glutamine synthetase activity in astroglial primary cultures after acute or long-term exposure for mercury or lead. (Submitted).

77 Engle MJ, Volpe JJ. Glutamine synthetase activity of developing astrocytes is inhibited in vitro by very low concentrations of lead. Developmental Brain Research 1990;55:283-7.

78 Sierra EM, Tiffany-Castiglioni E. Reduction of glutamine synthetase activity in astroglia exposed in culture to low levels of inorganic lead. Toxicology 1991;65:295-304.

79 Wolfe BB, Harden TK, Sporn JR, Molinoff PB. Presynaptic modulation of beta-adrenergic receptors in rat cerebral cortex after treatment with antidepressants. J Pharmacol Exp Ther 1978;207:446-57.

80 Johnson RD, Iuvone PM, Minneman KP. Regulation of alpha-1 adrenergic receptor density and functional responsiveness in rat brain. $J$ Pharmacol Exp Ther 1987;242:842-9.

81 Greenamyre JT. The role of glutamate in neurotransmission and in neurologic disease. Arch Neurol 1986;43:1058-63.

82 Schmidt-Kastner R, Freund TF. Selective vulnerability of the hippocampus in brain ischemia. Neuroscience 1991 (in press).

Accepted 19 August 1991 